\title{
MUSIC AS A CULTURAL DIPLOMACY BETWEEN ISRAEL AND TURKEY (2008-2016)
}

\author{
Mehtap DEMIR ${ }^{1}$
}

\begin{abstract}
ÖZ
The objective of this research is to explore how musical and cultural diplomacy have influenced political relationships between Turkey and Israel. Cultural diplomacy encompasses the exchange of ideas and information for the purpose of promoting mutually benefiting understanding between different cultural groups. Music diplomacy is the use of songs to promote respect, cooperation and understanding. The article emphasizes how Israel and Turkey have benefited from the power of music and cultural exchanges to maintain friendly ties when they have the lowest level of connection in terms of diplomatic relations. In the diplomatic crisis of two countries in 2010, the musicians, from both countries, took on the roles of peace ambassador and helped to soothe the masses through concerts. Using the constructivist theory of international relations, this article argues for promotion of culture and music as crucial diplomatic instruments for improving cooperation and communication between countries. In this context, it is very crucial to raise the highest possible levels of musical and cultural diplomacy between Israel and Turkey and to find ways to respect each other's cultural uniqueness. The topic of this article has been probed through the historical and critical method of musicology in the interdisciplinary context, including politics, international relations and cultural studies.
\end{abstract}

Keywords: Israel, Turkey, Cultural Diplomacy, Music, International Relations

Demir, Mehtap. "Music as a Cultural Diplomacy between Israel and Turkey (2008-2016)". idil 6.32 (2017): 1225-1240.

Demir, M. (2017). Music as a Cultural Diplomacy between Israel and Turkey (2008-2016). idil, 6 (32), s.1225-1240

${ }^{1}$ Assist. Prof. Dr., İstanbul University, State Conservatory, Ethnomusicology and Folklore Program, mehtapdem(at)gmail.com 


\title{
ISRAIL VE TÜRKIYE ARASINDA BIRR KÜLTÜREL DIPLOMASI OLARAK MÜZIK (2008-2016)
}

\begin{abstract}
$\mathrm{Bu}$ araştırmanın amacı, müziksel ve kültürel diplomasinin Türkiye ile İsrail arasındaki siyasi ilişkileri nasıl etkilediğini araştırmaktır. Kültürel diplomasi, farklı kültür grupları arasındaki karşılıklı yararlanmayı teşvik amacıyla fikir ve bilgi alışverişini kapsar. Müzik diplomasisi, saygı, işbirliği ve anlayışa yönelik şarkıların kullanılmasıdır. Makale, İsrail ve Türkiye'nin, diplomatik ilişkiler açısından en düşük düzeyde bağlantıya sahip oldukları zaman dostça bağları korumak için müzik ve kültür alışverişi güçlerinden nasıl yararlandıklarını vurgular. 2010'da iki ülkenin diplomatik krizi sırasında, her iki ülkenin müzisyenleri barış elçisi rollerini üstlenmiş ve kitleleri konser yoluyla rahatlatmaya yardımcı olmuşlardır. Bu makale, yapılandırmacı uluslararası ilişkiler kuramını kullanarak kültür ve müziğin ülkeler arasındaki işbirliği ve iletişimi geliştirmeye yönelik önemli diplomatik araçlar olduğunu irdeler. $\mathrm{Bu}$ bağlamda, İsrail ve Türkiye arasında müziksel ve kültürel diplomasiyi mümkün olan en üst düzeye yükseltmek ve biribirilerinin kültürel eşsizliğine saygı duymanın yollarını bulmak çok önemlidir. Bu makalenin konusu, siyaset, uluslararası ilişkiler ve kültürel çalışmalar da dahil olmak üzere disiplinlerarası bağlamda müzikolojinin tarihsel ve eleştirel yöntemi aracılığıyla araştırılmıştır.
\end{abstract} İlişkiler

Anahtar Kelimeler: İsrail, Türkiye, Kültürel Diplomasi, Müzik, Uluslararas1 


\section{Introduction}

Cultural diplomacy is a concept that is widely used in international relations and politics. It refers to the process of exchanging information, ideas, art and other elements of culture among groups of people and nations to create an environment of mutual understanding (Lenczowski, 2007). As it is know, the term "cultural diplomacy" was coined by Milton Cummings and he defined it as "the exchange of ideas, information, art and other aspects of culture among nations and their peoples to foster mutual understanding" (Cummings, 2009: 1).

Culture is a large framework that contains many elements. Cultural diplomacy consists of emotional communication among countries through cultural elements such as art. Thus, cultural diplomacy is a form of non-political communication between countries.

At the basic level, cultural diplomacy entails any activity or process that leads to the exchange of values, ideas, traditions and identity for the purpose of enhancing cross-border cooperation, strengthen relationships and advance national interests for the long-term benefits of a nation and its people (Einbinder, 2013). As an integral factor in the increasing globalization and interconnectedness between the various global communities, cultural diplomacy is founded on several key principles. These include recognition and appreciation of cultural diversity, intercultural dialogue, protection of human rights, international peace and stability, interdependence and equality.

Cultural diplomacy is a two-way process of dialogue between different foreign societies to improve the image and values of a nation and to try to understand the cultures, values and images of other countries and peoples. It is a means by which governments can increase their level of respect and understanding among the other countries of the world (Wyszomirski, Burgess \& Peila, 2003: 4).

Musical diplomacy is closely related to the concept of cultural diplomacy. It refers to the use of music to promote mutual understanding, respect and cooperation between communities and nations. Being one of the most important aspects that distinguish the various cultures in the world, music has the unique ability to reach beyond the common mediums of political diplomacy and unite cultures regardless of differences in traditions, norms, and values (Albert, Kessler \& Stetter, 2008). Music can improve understanding across cultures and serve as a medium of intercultural communication. As such, musical diplomacy can contribute immensely to peace building and management of conflicts among nations. By providing a platform for a country to showcase its culture to the citizens of another country, musical diplomacy 
serves the important purpose of enabling a country to make its internal and foreign policies more appealing to a larger audience.

There are many theories in international relations that attempt to explain the concepts of cultural and musical diplomacy. These include liberalism, realism and constructivism. This article will focus on the constructivist view of international relations. The basic premise of the constructivism theory is that international relations are a platform for interactions through which a state's identities are molded. International relations is a complex phenomenon that encompasses human values, beliefs, and consciousness (Einbinder, 2013).

Many studies about the importance of cultural diplomacy among countries have been published. Gienow-Hecht (2009) examined cross-cultural interactions through cultural and musical diplomacy between America and Germany. She notes that efforts related musical diplomacy are as an instrument of non-governmental diplomacy. Kitsou (2011) stressed the strength of the US cultural diplomacy in France and Germany. She presents that culture is a power in diplomacy. Von Eschen (2004) noted that during the Cold War, musical diplomacy overcame tensions with the Soviet Union under the leadership of the United States. From the perspective of examples, the strength of cultural diplomacy may be more than the political diplomacy. This article presents critical analyses of how musical and cultural diplomacy has influenced relationship between Turkey and Israel.

As exemplified in the sources, the reflection of cultural diplomacy through music in the context of a non-political relationship between countries has been examined between Turkey and Israel in this study. The political problems that broke out between the two countries in 2008 have improved somewhat in 2016. Despite the political problems these years, the continuity of the artistic relationship between the two countries has been assessed in the context of cultural diplomacy. Therefore, Turkey and Israel and 2008-2016 years are the sampling that constitute the limit of this study.

The article uses the constructivist theory of international relations to underscore the fact that music and cultural diplomacy can enhance intercultural communication and improve cross-cultural understanding. As such, music and culture have potential for peace building and depends greatly on the efforts of the artist as a cultural diplomat. The current research is based on an analysis developed through experiential, grounded studies involving interviews, fieldwork, performance analysis and participation in music performances. In this context, although research is theoretically included in ethnomusicology, it has been examined with historical and critical methods of musicology because it basically is based on document analysis. 


\section{Significance of Cultural and Musical Relationship}

In today's politically turbulent world, diplomatic channels play an increasingly crucial role in promoting an appealing international image for both Israel and Turkey. Ideally, neither country can afford the use of military threats or economic means to build and maintain mutually benefiting relationships with other nations (Appel, et al., 2008). Instead, most countries maintain high-level departments whose responsibility is to foster the mutual relations and solicit for understanding in important issues. Among other things, these departments (especially the Ministry of Foreign Affairs) seek to promote intercultural exchanges through musical and cultural diplomacy.

It is important to explain musical and cultural diplomacy for a variety of reasons. First, globalization brought with it increased challenges such as cross-border crimes, terrorism, illegal immigration, environmental pollution, and piracy. These challenges have created an unstable security environment that has never existed. Today, no country can provide its security. Accordingly, interdependence among countries has become an important feature of modern state relations. Secondly, the rate of change in the modern world has gone a notch higher, making the global environment very fragile. In such an environment, the strength of a country in the international arena is determined by the level of integration with other countries. Cultural and musical diplomacy provide a platform for fostering the integrations (Brink-Danan, 2011). Through their respective ministries of foreign affairs, Turkey and Israel have used cultural and musical diplomacy (Einbinder, 2013). The two countries have contrasting cultural values, because while Turkey is predominantly Islamic, Israeli is a Jewish state. However, the two countries have deep historical ties originating from the time when the territory of Israel was part of the Ottoman Empire (which is the modern day Turkey).

In the restoration of the relationship between Turkey and Israel, cultural diplomacy played a critical role with a positive way. Interactions through the exchange of music, art, ideas and language improved communication between the two countries (Nachmani, 2003). In the aftermath of the flotilla attack, musicians and other artists from Israel visited Turkey and performed in hundreds of concerts in various cities. Similarly, Turkish artists performed in several Israeli cities, prompting unprecedented levels of cultural exchange between the two countries. Essentially, there is an invincible musical bond between Israel and Turkey and it does not appear to be influenced by political maneuvers. Considering Israel's tinted image in the Muslim world, music is a priceless but an often neglected tool that can be used to improve the country's public image. The volunteer cultural diplomats are organizing concerts music festivals, which can demonstrate the friendship of Jews and Muslims in Israel's important cultural centers such as Israeli Andalousian Orchestra Ashdod, 
The Jerusalem Andalusian Orchestra, The Mediterranean Andalusian Orchestra of Ashkelon Jewish, Muslim and Christian members. The ud festival, which has been organized for years, has done great volunteer work on this subject.

According to Ziffer (2012), increasing cultural ties between Turkey and Israel have fundamental implications not just for the two countries but the Middle East region as a whole. Although their official diplomatic relations are highly controversial, musical and cultural exchanges between them are likely to foster longlasting stability in one of the most unstable regions in the world. Notably, musical and cultural diplomacy both in the state of official status and in unofficial individual voluntary initiatives will enhance military cooperation, tourism, and commerce between the Middle East's only democracies.

Perhaps, the most important area that will benefit most from the renewal of cultural and musical diplomacy between Israel and Turkey is the education sector. According to Albert, Kessler \& Stetter (2008), cross-cultural musical education can foster high levels of intercultural understanding between societies that profess different value systems, traditions and practices. This can ostensibly help in bringing about an environment of peace and mutual understanding. However, for citizens from the two countries to develop intercultural understanding, they cannot remain attached to their respective national identities, supporting systems or expressions. Rather, they should be willing to understand and appreciate the other culture's aesthetics and values. Most of professional Israeli musicians learned to play instruments like the ud rhythm in Turkey. And they are now giving lessons in Jerusalem and Telaviv such as Ellad Gabay, Ariel Quasis who also have the music band called "İstiklal Trio". Musicologist Hadas Pal Yarden came to İstanbul for her fieldwork and she remined to the people Sephardic songs of Turkey with an recordings. Another musicologist Mehtap Demir made workshops in Jerusalem and teach to the students Maftirim songs which is Jewish Paraliturgical songs derive from Edirne Turkey. In this point the article have to explain historical-Cultural Ties Between the Israel and Turkey.

\section{Historical-Cultural Ties Between the Jews and the Turks}

The Jews and the Turks have been maintaining strong cultural and historical ties spanning at least for two millennia. During the 1st century AD, the Roman Empire extended its territory eastwards and reached the lands of Judea and Samaria. The Jews who lived in these lands (including the city of Jerusalem) fled to Spain where they established small Jewish communities. For many years, the Spanish Jews lived happily and did not experience any major difficulties about their unique religion and culture. All this time Spain was ruled by Muslim rulers who crossed from North Africa to establish religious colonies in Europe. Towards the end of the 13th century 
$\mathrm{AD}$, the Muslims were driven out of Spain by Christians who established Spain as their new religious center. The new rulers decreed that all people convert to Christianity, a rule that drove the Muslims back to North Africa (Neyzi, 2005).

In the 14th and 15th centuries, the Spanish Jews faced strong pressure to convert to Christianity. Those who did not convert were expelled to other countries. The rulers of the Ottoman Empire issued a decree welcoming the Jews who were fleeing the forceful conversion in Spain (Nachmani, 1998). The empire had encouraged the policy of religious tolerance because its territory extended over vast areas and cut across diverse religions. Thus, a significant number of the Jews fleeing Spain settled in Turkey, largely on the European side of the vast empire. These Jews came to be known as the Sephardic Jews (Ottoman Jews) and are credited with fostering the first ever cultural relations between the Jewish community and Muslim Turks.

In the subsequent centuries, successive Ottoman rulers, as well as the modern day Republic of Turkey, offered a haven to persecuted Jews especially those who lived European countries. The Jews arriving from Spain brought with them new systems of communication such as the printing press which had just been invented. During World War II, the Jews living in Turkey were the only ones who were not persecuted because of the strong support they enjoyed from the Turks. When the state of Israel was established in 1948, Turkey became the first Muslim country to recognize it (Schulze, n.d). Overall, the history of Jewish-Turkish interactions is rich with cultural influences on both sides.

\section{Crisis Years in Turkey and Israel Relations Between 2008 and 2016}

Although Turks and Jews have deep historical and cultural ties, the relations between them sank to the lowest levels between the years 2008-2016 (Nasi, 2017). Strained relations between the two countries began to emerge when in 2008 Turkey condemned Israel's invasion of Gaza (TRT World, 2016). The Israel army had waged a major offensive against Gaza ostensibly to stem out Hamas terrorists. In the ensuing conflicts, hundreds of Gaza residents were killed and thousands more injured. Also, Palestinian civilian infrastructure and property worth billions of dollars were damaged. Worse, the Israel government blocked Gaza, meaning that no humanitarian aid could enter the Palestinian territory. During the 2009 World Economic Forum conference in Switzerland, Turkish Prime Minister Recep Tayyip Erdoğan criticized the Israel offense in Gaza. The criticism heightened tensions between the two countries (Inbar, 2011). 
The bad relations between the two countries took a notch higher after Israel attacked a Gaza-bound Turkish flotilla in 2010. The flotilla was from Turkey and was carrying humanitarian aid (food and medical supplies) (Nasi, 2017). The ships refused an Israeli offer to deliver the goods to Ashdod. On May 31, Israeli naval special forces intercepted the convoy in international waters. They took control of five of the ships without resistance. However, some activists on a large Turkish passenger vessel challenged the commandos. The confrontation resulted in eight Turks and one Turkish-American killed, more than 20 passengers injured, and 10 commandos injured (Migdalovitz, 2010).

The government of Turkey described the invasion of the flotilla as an act of terrorism. Immediately, the Turkish Ambassador to Israel was recalled. The government of Israel refused to express regrets over the incident causing relations between the two countries to become more constrained. Neighboring countries sided with Turkey and condemned Israel for attacking a civilian vessel. In more profound ways, the flotilla incident led to further isolation of Israel in the region.

The strained relations between the two countries continued into late 2011 when Turkey suspended military and security engagements with Israel. Turkey also downgraded its diplomatic relationships with Israel. This was after the United Nations released a condemning report against Israel regarding the attack on the Turkish ships (AFP, 2015). Turkey demanded not only an apology but also compensation from Israel and an assurance that such incidents would not be allowed to recur. Despite the deteriorating political relations, the two countries maintained strong business ties. The need to maintain business ties perhaps compelled Israel to reconsider its diplomatic relations with Turkey and other neighboring countries (Nasi, 2017).

Under duress from the United States, Israel was pressed to apologize formally to Turkey. The apology happened in 2013 when the prime minister of Israel telephoned his Turkish counterpart to apologize over the 2010 ship raid (Nasi, 2017). After long discussion procces the officials made procedural agreement on compensation between the Republic of Turkey and State of Israel. Israel offered $\$ 20,000$ ex gratia for the attack and pledged to ease the longstanding blockade on Gaza. In mid-2015, top diplomats from the two countries held a series of meetings to deliberate on ways of normalizing relations. A key outcome of these deliberations was the resumption of diplomatic ties. Moreover, Israel accepted to allow Turkey to access Gaza through Israeli ports. Essentially, relations have normalized as can be evidenced by the fact that in July 2016, Israel allowed Turkey to ship 10,000 tons of aid to Gaza (T.C. Başbakanlık, 2016).

\section{Cultural and Musical Relationships during the Crisis Years (2008-2016)}


Although political means played a key role in restoring relations between Israel and Turkey during the crisis years, cultural and musical diplomacy played an equally important role. As a matter of fact, several event-concerts and cultural movements were held between 2008 and 2015. At the height of the battered diplomatic relations, musicians from both countries took the initiative to bridge the political differences (Tokyay, 2012). Although music does not have the ability to bridge feuding parties at government-to-government levels, it stimulates high levels of people-to-people contact which help in creating mutual understanding between cultures. It is for this reason that musicians from both countries have crossed the Mediterranean numerous times to be the ambassadors of good neighborhood and cultural tolerance.

There are numerous examples which show that the two countries have used music to bolster cultural tolerance and understanding. For example, Yinon Muallem, an Israeli music composer and percussionist has performed in Turkey with leading Turkish musicians such as Tekfen Philharmonic, Sirin Pancaroglu, and Omer Faruk Tekbilek. Muallem is not only a Turkey-based Israeli musician but is also the cultural attaché of Israel in Turkey. In his capacity as a cultural attaché, he is a high-ranking official diplomat whose primary responsibility is to promote the culture of his country in the Muslim-majority country. Muallem works closely with other cultural ambassadors such as writers and artists to promote the image of their country. The numerous performances that he performed across Turkish cities helped soften people's stance towards Israel considering that the two countries were going through a period of heightened tension. Muallem is not the only high-ranking Israel musician to have taken the voluntary initiative to promote mutual understanding between Israel and Turkey through music.

Israel's leading metal band, Orphaned Land, has been staging concerts and performances in the Muslim country since 2001. During the crisis years, the band did not hesitate to show support for the speedy resumption of diplomatic ties between the two countries. For instance, the band made a much-hyped visit to Turkey in February 2012. The performance attracted tens of thousands of Turkish fans. Orphaned Land is so popular in Turkey that in 2010 it won a prestigious peace prize from the Istanbul Commerce University (Tokyay, 2012). The award was in recognition of Orphaned Land's contribution to the strengthening of cultural relationships between Muslims and Jews. Many of the Orphaned Land's songs are based on verses from Jewish liturgy, the Holy Quran, and other religious texts. In an attempt to boost cultural ties between Israel and Turkey, the Orphaned Land collaborated with leading Turkish rock musicians such as Erkin Koray. Such collaborations are symbolic of close friendships between the peoples of the two countries. 
During the crisis period, tens of high-ranking Turkish musicians performed in Israel. For example, Cem Mansur is a famous conductor of Turkey, the origin of his family is Jewish, conducted the three concerts in the Israeli city of Haifa in 2012. The concerts were attended by thousands of Israel citizens and proved that music can unite people, even during periods of adversity (Hugi, 2013). One notable thing about Mansur's style of music is that it is founded on the philosophy of promoting mutual understanding and religious tolerance in the world. This philosophy is reflected in the messages of the works conducted by Mansur. It was for this reason that the musician was able to attract thousands of Israel listeners despite the damaged relationship between Turkey and Israel.

Another major incident of cultural diplomacy between Israel and Turkey happened in 2011 when Itamar Erez (an Israel guitarist) made a concert tour of Turkey. During these concerts, Erez performed alongside renowned Turkish musicians such as Omer Faruk Tekbilek. He not only attracted a large number of local fans but also used the opportunity to dispel fears of further escalation in the relationships between his country and Turkey (Hugi, 2013). His songs communicated messages of brotherhood, tolerance, and reconciliation. In essence, Erez acted as a volunteer cultural diplomat and a positive force for reconciliation at a time when both countries were desperate of renewing ties for the sake of their people. Yasmin Levy, an Israel music composer, and singer who has always performed in Istanbul follows in the footsteps of many musicians who have taken it upon themselves to use cultural exchanges to bridge any diplomatic gaps between the two countries.

It is worth mentioning that the heightened tensions between Israel and Turkey between 2008 and 2016 not only affected relationships between the two countries but also enlivened the decades-old hatred of regional countries against Israel. In any event, the Turkish-Israel tensions were exacerbated by Israel's invasion of Gaza, an Arab territory. As such, regional Arab and Muslim countries joined hands in condemning Israel. For this reason, Israel focused not only on normalizing ties with Turkey but also the other neighboring countries. During the 2011 Jerusalem International Oud Festival, Israel allowed musicians from several Arab countries to attend the festivals and perform. The festival was a great opportunity for the Jewish to reaffirm their strong cultural ties with Arabs notwithstanding the ongoing conflict between Israel and Palestine.

Notable Turkish musicians who performed during the Jerusalem Festival included Sabahat Akkiraz, who stood out not only because of her stellar performance but because she was a sitting member of parliament in Turkey (Ziffer, 2012). Akkiraz is the top most ranking official from Turkey's parliament to have performed in an international cultural event. As such, her appearance in the Jerusalem festival was an 
indication that Turkey was on a path of reconciliation with Israel. Another example Kurdish rooted singer from Turkey who is singing Kurdish and Turkish folk songs Aynur Dogan performed during the event.

In 2014, Israeli film director Roy Sher with the Turkish singer Mehtap Demir, Greek singer Martha and Israeli oud player Tomer Katz made important concerts in the Israeli cities of Jerusalem and Tel Aviv. The concerts were attended by thousands of Turkish and Israeli nationals, and served as a platform for showcasing the strong cultural ties between the two countries. The performers also made a documentary about Ottoman-Jewish singer Roza Eskenazi (Barton, 2014).

In 2014, Harel Shachal band named "Ottoman Band", performed in Jaffa, Israel. The performance consisted of ancient Ottoman music and attracted a huge audience comprising of both Israel and Turkish nationals (Fiske, 2014). The performance was an opportunity to showcase and foster strong cultural ties between the two countries. In the same year, a musical conference was held in the Israeli city of Jerusalem. Dubbed the "Mediterranean Musical Dialogue", the conference brought together musicians and other stakeholders from the Mediterranean region to focus on ways of fostering strong diplomatic ties using music (Bilitzky, 2011). A similar conference was held in the Turkish city of Mersin (Belen Alonso Management, n.d).

In March 2016, two cultural events were held simultaneously in Tel Aviv and Istanbul. Dubbed the Sound Ports Festival, the purpose of these events was to create cultural bridges between the two largest capitals of the Middle East. Istanbul and Tel Aviv have influenced each other both economically and culturally for a very long time (Gedalyahu, 2012). The 2016 events were an opportunity for the citizens of the two countries to blend and explore each other's culture not only regarding music but also cuisines, record fairs, lectures, and exhibitions. Going forward, the Sound Ports Festival promises to be an annual event whose primary focus is on bringing the people of the two countries together. Inevitably, the event will go a long way in using culture to harmonize diplomatic and political relations between the two countries.

The various music events helped the citizens of Israel and Turkey to develop new thinking and to appreciate cultural differences based on knowledge of each other. In the history of the two countries, no major events have been able to unite people from the two countries for the purpose of promoting diplomatic ties through music (Gedalyahu, 2012). In this regard, the numerous performances were an effective tool for enabling the people to forget the common challenges facing their countries. One thing that keeps music and culture an even better tool for diplomacy is that they are directed at the masses and not the government. This way, mutual friendship is created between the masses even if their countries are in a state of adversity. 
Indeed, many Israeli musicians have worked with their counterparts even from countries that maintain nil diplomatic relations with Israel. These countries include Iran and Syria, an indication that cultural ties transcend greater boundaries than political ties. Whenever musicians from foreign countries perform in Israel, they do not feel any alienation (Ziffer, 2012). This is a clear indication that in as much as Israel may harbor political differences with other countries, it is not in her interest to promote hatred between her people and those of other countries. By allowing unrestrained cultural exchanges through music, Israel's actions are an affirmation that it values the culture as an important vessel of international peace and understanding.

On te other side, there was an Istanbul concert by an award-winning musician Yuval Ron of Israeli descent has been cancelled due to alleged threats from a Turkish nongovernmental group (Ziflioğlu, 2011). Despite the negativities they experienced between 2008 and 2016, such as Riff Cohen and Itamar Eretz used a language of constructive and friendly discourse (Ben Tal, 2012; Lieber, 2015).

In fact, although it seems as if there is no contribution to the official associations, all these voluntary cultural diplomacy movements, It strengthens the invisible ties between these countries. The sensitivity and effort that artists show to cultural initiatives opens the way for the reproduction and continuity of the culture between the two countries. If this artist's naivetism and cultural space creation were otherwise the reaction of the official channels could be harder.

\section{Conclusion}

Culture and music have the power to influence political relationships and geopolitical ties between countries. In the modern world where many countries are involved in endless conflicts, cultural and musical diplomacy provides an effective platform for projecting a positive image to the international community. Although not as effective as political means, both music and culture provide priceless avenues for constructing channels that can be used to support foreign policy objectives. In practice, musical and cultural diplomacy are often considered a subset of the political diplomacy and function in tandem with other means to advance international policies. During periods of conflicts, countries can use cultural and musical ties to develop mutual understanding, project positive reputation and combat national stereotyping.

The discussions in the previous sections have shown that Israel and Turkey have harnessed the power of cultural and musical diplomacy to strengthen diplomatic ties during difficult moments. Several high-level musical and cultural events involving Israel and Turkey have been held during the 2008-2016 crisis period. These events not only facilitated the exchange of information and ideas between the countries but also 
facilitated mutual understanding between the Jews and the Muslims. The willingness of both countries to welcome each other's musicians is sufficient illustration that music and other cultural aspects keep relations warm even during the most difficult moments. In a way, cultural diplomacy provides a constructive and safe forum for easing of tension. Overall, music and other cultural events have played a crucial role in building strong relations between Israel and Turkey. Considering a large number of cross-border cultural events pitting the two countries, it is plausible that cultural diplomacy can be an effective instrument for supporting the foreign policy objectives of the Israeli and Turkish governments.

Therefore, it is imperative for countries to consider cultural and musical diplomacy as indispensable tools of foreign policy.

\section{Acknowledgement}

I would like to thank you Musicologist Seyit Yöre (Prof., Phd.) for his editorial contributions to my article.

\section{REFERENCES}

AFP. "Reconciliation pact struck with Turkey: Israeli official," Mail Online (2015, December 17), http://www.dailymail.co.uk/wires/afp/article3364786/Reconciliation-pact-struck-Turkey-Israeli-official.html, 2017, February 28.

Albert, Mathias, Kessler, Oliver and Stetter, Stephan. "On order and conflict: International relations and the "communicative turn," Review of International Studies 34, S1 (January 2008): 43-67, https:/www.cambridge.org/core/journals/review-ofinternational-studies/article/div-classtitleon-order-and-conflict-international-relationsand-the-communicative-turndiv/94901240A95902EC4252C7EF6FCE5EFA， 2017, February 28.

Appel, Ronit, et al. Cultural Diplomacy: An Important but Neglected Tool in Promoting Israel's Public Image. The Interdisciplinary Center Herzliya Lauder School of Government, Diplomacy and Strategy Argov Fellows Program in Leadership and Diplomacy, 2008, http://portal.idc.ac.il/sitecollectiondocuments/cultural_diplomacy_seminar_paper1.pdf , 2017, March 3. 
Barton, Laura. "Roza Eskenazi: Canary of the Aegean," The Guardian (2014, November 04), https://www.theguardian.com/music/2014/nov/04/roza-eskenazi-mysweet-canary, 2017, February 28.

Belen Alonso Management. "Mersin Internaional Festival," (n.d.), http://belenalonsomanagement.com/mersin-festival-in-a-free-spirit/, 2017, February 15.

Bilitzky, Hagai. "Mediterranean Musical Dialogue," (2011, October 24), http://www.doublebasseast.com/blog/2011/10/24/mediterranean-musical-dialogue/, 2017, February 17.

Brink-Danan, Marcy. Jewish life in 21st-Century Turkey: The Other Side of Tolerance. Bloomington, Indiana: Indiana University Press, 2011.

Cummings, Milton C. Cultural Diplomacy and the United States Government: A Survey. Washington DC: Center for Arts and Culture, 2009, http://www.americansforthearts.org/sites/default/files/MCCpaper.pdf, 2017, May 4.

Dorell, Oren. "Closing flotilla raid rift opens gas talks for Israel, Turkey," USA Today (2016, June $27)$, http://www.usatoday.com/story/news/world/2016/06/27/netanyahu-lauds-benefitsnormalizing-ties-turkey/86422404/, 2017, February 15.

Einbinder, Mary. Cultural Diplomacy: Harmonizing International Relations through Music (Master of Arts Thesis), New York University, 2013.

Fiske, Gavriel. "Can musical harmony rise above the wreckage of IsraelTurkey ties?" The Times of Israel (2014, November 30), http://www.timesofisrael.com/can-musical-harmony-rise-above-the-wreckage-ofisrael-turkey-ties/, 2017, February 27.

Gedalyahu, Tzvi Ben. "Israeli heavy metal band to become Turkish citizens," Arutz Sheva (2012, July 07). http://www.israelnationalnews.com/news/news.aspx/157713, 2017, March 3.

Gienow-Hecht, Jessica. Sound Diplomacy: Music and Emotions in Transatlantic Relations, 1850-1920. Chicago: University of Chicago Press, 2009.

Hugi, Jacky. "Musical bridges between Israel and Turkey," Al-Monitor (2013, May 28), http://www.al-monitor.com/pulse/originals/2013/05/the-musician-whobridges-between-israel-and-turkey.html, 2017, February 15. 
Inbar, Efraim. 2011, "Israeli-Turkish Tensions and their International. Ramifications," Orbis 55, 1 (December 2011): 132-146, DOI: 10.1016/j.orbis.2010.10.005, 2017, May 6.

Kitsou, Sofia. "The Power of Culture in Diplomacy: The Case of U.S. Cultural Diplomacy in France and Germany," Exchange: The Journal of Public Diplomacy, 2, 1 (2003), 21-39, http://surface.syr.edu/exchange/vol2/iss1/3, 2017, May 4.

Lenczowski, John. Cultural Diplomacy, Political Influence, and Integrated Strategy. Washington, D.C.: The Institute of World Politics, 2007.

Lieber, Nick. "Israeli Musician Riff Cohen Receives 'Big, Huge Hug' From Turkish Fans," Creative Community for Peace (2015, September 17), http://www.creativecommunityforpeace.com/israeli-musician-riff-cohen-receives-bighuge-hug-from-turkish-fans/, 2017, May 6.

Migdalovitz, Carol. "Israel's Blockade of Gaza, the Mavi Marmara Incident, and Its Aftermath," CRS Report for Congress (2010, June 23), https://fas.org/sgp/crs/mideast/R41275.pdf, 2017, May, 7.

Nachmani, Amikam. "The remarkable Turkish-Israeli tie.," Middle East Quarterly 5, 2 (June 1998): 19-29, http://www.meforum.org/394/the-remarkableturkish-israeli-tie (2017, March 2).

Nachmani, Amikam. Turkey: facing a new millennium. Coping with intertwined conflicts. NY: Manchester University Press, 2003.

Nasi, Selin. "Turkey-Israel deal: A key to long term reconciliation," IsraelTurkey Policy Dialogue Publication Series (January 2017), http://s3-eu-central1.amazonaws.com/fes-org-il-wp/wp-content/uploads/2017/01/10110901/TurkeyIsrael-Deal.pdf, 2017, February 25.

Neyzi, Leyla. "Strong as steel, fragile as a rose: A Turkish Jewish witness to the twentieth century," Jewish Social Studies 12, 1 (Autumn, 2005): 167-189, http://www.jstor.org/stable/4467726, 2017, March 2.

Schulze, Melanie. History of the Jews of Turkey: A Document-Based Question Unit for World. Austin: University of Texas (n.d.). http://liberalarts.utexas.edu/mes/_files/pdf/curriculum/Turkish_Jews_DBQ.pdf, 2017, February 19 
Tal, Daniel Ben. "How music can heal the Israel-Turkey rift," Israel21c (September 13, 2011), https://www.israel21c.org/how-music-can-heal-the-israelturkey-rift/, 2017, May 9.

T.C. Başbakanlık. "Kanun Tasarısı," (2016, August 16), http://www2.tbmm.gov.tr/d26/1/1-0754.pdf, 2017, May 8.

TRT World. "13 key moments in Turkish-Israeli relations," (2016, Jun 28), http://www.trtworld.com/in-depth/13-key-moments-in-turkish-israeli-relations-93510, 2017, February 16.

Tokyay, Menekse. "Turkey and Israel keep bonds alive through music," The Jerusalem Post (2012, February 27), http://www.jpost.com/Diplomacy-andPolitics/Turkey-and-Israel-keep-bonds-alive-through-music, 2017, February 16.

Von Eschen, Penny M. Satchmo Blows Up the World: Jazz Ambassadors Play the Cold War. Cambridge, Mass.: Harvard University Press. 2004.

Wyszomirski, Margaret J., Burgess, Christopher and Peila, Catherine. International Cultural Relations: A Multi-Country Comparison. Washington DC: Center for Arts and Culture, 2003, http://www.americansforthearts.org/sites/default/files/MJWpaper_0.pdf, 2017, May 4.

Ziffer, Benny. "Musical diplomacy between Turkey and Israel," Haaretz (2012, August 31), http://www.haaretz.com/israel-news/musical-diplomacy-betweenturkey-and-israel-1.461992, 2017, March 2.

Ziflioğlu, Vercihan. "Yuval Ron concert in Istanbul canceled due to alleged threats," Hürriyet Daily News (2011, October 6), http://www.hurriyetdailynews.com/yuval-ron-concert-in-istanbul-canceled-due-toalleged-threats.aspx?pageID $=438 \& n=y u v a l-r o n-c o n c e r t-c a n c e l e d-b e c a u s e-o f-t h r e a t s-$ 2011-06-10, 2017, May 8. 